\title{
Our Global Environment and the World Campaign for The Biosphere
}

\author{
by \\ NICHOLAS POLUNIN, D.Phil., D.Sc.(Oxon.), CBE \\ President of the Foundation for Environmental Conservation; \\ Secretary-General and Editor of the International Conferences on Environmental Future; \\ Founder and Editor of Environmental Conservation; \\ Convener and General Editor of Environmental Monographs and Symposia, \\ 15 Chemin F.-Lehmann, 1218 Grand-Saconnex, Geneva, Switzerland.
}

\section{INTRODUCTION}

This account was written (and subsequently approved by critical referees) in compliance with requests to ex. plain how we came to recognize and care about our Only One Biosphere, and hence to propose a 'World Campaign'* in its support, while also updating our thoughts on what might best be done to further the Campaign and make it operationally effective-primarily as an educational device, and secondarily to engender action.

It was in the summer of 1966, at a conference in Finland which had been well organized by UNESCO, that we finally realized how our beautiful world was being threatened by the inexorable rise of human populationpressures. So we decided henceforth to do our utmost to warn people widely of the extreme gravity of the impending situation, even if it should mean relinquishing our last Chair - as indeed it did, inter alia to found a muchneeded international journal and then another.

In our earlier student days the global population had seemed manageable; but we had the globalist view of 'one world' thrust upon us on realizing that dust, identified from the paroxysmal eruptions of Krakatoa (Krakatau) nearly 50 years earlier in the then Dutch East Indies, had drifted at least three times around the world, persistently reddening sunsets and widely darkening the sky, in the mid-1880s before finally settling to land or ocean or otherwise 'disappearing'.

In my later student days, in 1933, I exposed nutrient Petri-plates to northerly winds on mountain-tops in northern Lapland and West Spitsbergen, and caught on both occasions so many fungal spores and Bacteria on the nutrient-rich media that $I$ thought they must have been contaminated and consequently did not publish my observations. Yet they were probably quite valid, as emerged in 1948 when, using American aircraft and various devices for collecting and sampling, specialist colleagues and I were able to demonstrate the occurrence of 'botanical particles' - such as pollen grains, yeasts, fungal spores, and Bacteria, many of which were still viable - in the atmosphere at the highest latitudes and in some cases almost directly over the geographic North Pole (Polunin, 1951 $a$; Polunin \& Kelly, 1952). Meanwhile,

\footnotetext{
*Formerly called a 'Decade', but now renamed for reasons explained on page 92 of this issue (following its 'Declaration' on pp. $91-2$ ).-Ed.
}

in that same far-off summer of 1933, the aviator Charles A. Lindbergh had exposed sticky slides in the air over Davis Strait and East Greenland, with apparently comparable results to my own obtained in Lapland and Spitsbergen (Meier \& Lindbergh, 1935; cf. Gregory, 1973).

Following the war we resumed our arctic exploration with the help of various aircraft, though these immediately swept away the challenge that we had met in earlier times by foot-slogging and other laborious means. Thus in 1946, flying in a Canso amphibious aircraft of the Royal Canadian Air Force, after confirming the existence of the Spicer Islands in Foxe Basin north of Hudson Bay, we sighted to their east the last major islands to be added to the world map and now called Prince Charles Island and Air Force Island. The conviction that there could scarcely be any other terrestrial features of such magnitude remaining undiscovered on Earth gave us again the feeling of one-world globalism. Then two years later, having been given the use of a United States Air Force B29 'Superfortress' and crew to investigate the spore content of the atmosphere around the North Pole, we had thrust on us yet again the now-evident oneness of the world in that further connection.

Studies of the air-masses in which we were flying to and from the North Pole in 1948 indicated that they had come from the Great Plains before travelling for hundreds of kilometres over the largely ice-covered Arctic Ocean. So the Great Plains were seemingly the provenance of our 'botanical particles', as indeed the identity of the latter in some cases appeared to support (Polunin, 1951a; Polunin \& Kelly, 1952; Gregory, 1973, and works cited therein). Similarly supported were my suspicions of the preceding year when I had caught many such bodies, including rust (Puccinia) spores, on sticky slides and nutrient Petri-plates that I had exposed by hand from aircraft northwards to the Arctic Ocean coast and southwards from the vicinity of the magnetic pole on Somerset Island, NWT, Canada (Polunin et al., 1947, 1948; Polunin, 1951b).

Perhaps more unexpected was our observation that, in the summer of 1950 , the most abundant pollen grains in the air near ground-level at Kongsfjord, northwestern Spitsbergen, were of coniferous trees which did not grow within hundreds of kilometres (Polunin, 1955); and so we go on, with of course further pertinent observations by others (cf. Gregory, 1973). 
In 1971 we held our first International Conference on Environmental Future, in Finland mainly at Jyväskylä, and gave a paper on 'The Biosphere Today' in which our current globalist views were aired and further expanded (Polunin, 1972). Meanwhile the Universe was being explored-particularly by the Americans-and it was emerging as more and more likely that our planet supports the only forms of life at present in existence in our Universe, being indeed the 'Only One Earth'. This quoted phrase was the slogan of the United Nations Conference on the Human Environment, held in Stockholm in 1972, which at last brought to many politicians and leading decision-makers overdue recognition of the paramount importance of the environment for Man as well as Nature.

This and subsequent developments-such as the establishment of the United Nations Environment Programme, UNEP-did not, however, bring home to people generally the all-important facts that (1) The Biosphere constitutes a single integrated whole, (2) we humans form an integral part of it, (3) we are utterly dependent on its health for our own sustenance and more, (4) it is in several ways fragile, but (5) it is gravely threatened by various human activities and out-sized capabilities.

So we proposed a 'World Decade of The Biosphere' (Polunin, 1980a , 1980b, 1980c; Vallentyne et al., 1980a; Laconte et al., 1980), to run if possible from 1982 to 1992 which, incidentally, is just 500 years after the rediscovery of the New World by Europeans. Earlier we had proposed, with others, such an 'International Year' (Vallentyne et al., 1980b), which for various reasons did not materialize (cf. Vallentyne, 1980; despite Cloud, 1980). But the World Decade seemed to be catching on very widely in prospect already before being launched, ${ }^{*}$ which bodes well for the leading use of the World Campaign as a vehicle for educating people everywhere concerning The Biosphere and the above five numbered points about it, namely that it constitutes an integrated whole of which we humans form an integral part, that we are utterly dependent on it, that it is fragile - and yet gravely threatened by our activities.

So much for the background micro-history which I have been asked to record from a personal standpoint, and which recalls the experiences of our colleague Vallentyne (1981) in such matters as student experiences and the aftermath of atomic explosions as compared with volcanic ones (see also Worthington, 1982). Now let us consider The Biosphere as our life-supporting habitat - than which effectively we have no known alternative - and proceed to review some ways in which the much-needed World Campaign for The Biosphere can be promoted as an educational device and, hopefully, become operationally effective.

\footnotetext{
*Thus for example we have recently - since having the project returned to us by the world body to which we passed it on conception of the idea but found, after a wasted year and more of waiting, that they were unable to do much about it-received indications that another world body has formally endorsed the proposal, while at least two major regional organizations have established special committees to support the Campaign, as recorded later in this paper. - Ed.
}

\section{THE BIOSPHERE AS OUR LIFE-SUPPORTING HABITAT}

To our mind The Biosphere is best described as the peripheral envelope of the Earth together with its surrounding atmosphere so far down, and up, as living things exist naturally. It thus ranges from the deepest layers of soils and bottoms of 'troughs' in oceans, upwards to the highest levels of the atmosphere in which any form of life-including dormant spores and bacterial or other cells - is present at all normally, for we exclude artificial projections into space and descents into deep mines etc. (Polunin, 1980a, 1980c; 1982).

Although categorized primarily by the presence of life, The Biosphere of course has its inert components, and constitutes, in its parts and as a whole, the planetary life-support system of all Nature and Mankind. It thus embraces the unique intelligence and cognate capabilities of Man (comprising also women and children), which puts humans in such a position of power that they have emerged collectively as the world's undisputed pandominant (Johnson, 1980). Thus as species and other taxa of biota disappear and the potentialities for and of genepools become depleted, biologists in general, and plant scientists in particular, need to be personally concerned as well as professionally involved for their supply of materials to study as well as for subsistence. For the environment is liable to be so changed by ever-mounting human populations and their demands for food, raw materials, and living-space, that there is reason for everincreasing concern about the global life-support system.

Already our 'Only One World' and life as we know it seem gravely threatened in ways that are widely proliferating-basically through increasing population-pressure (demophora) with attendant pollution, erosion and soil-degradation, inequities of distribution to relieve cruel shortages, and concomitant threats of widespread famine and pestilence, pandemic disease, or nuclear holocaust. At the same time other, often more subtle, forces are also at work practically at Man's behestincluding the loss of more and more productive land to man-made structures or coverings, build-up of carbon dioxide in the troposphere, and increase of ozonedestroying substances in the stratosphere. Less-subtle forces engendering the gravest possible concern include the stupendous build-up of nuclear arms particularly on the two sides of the North Atlantic as stressed in our last Winter issue (e.g. Hiatt, 1981; Westing, 1981).

But lest I may seem like a morbid doomsayer, let me affirm that $I$ am a strong believer in the resilience of life and the capacity of humans to save their world if only they will realize the situation, recognize the growing dangers, and act widely in sufficient concert. For this a prerequisite is education-particularly concerning The Biosphere and the items of integrity, interdependence, insecurity, and threatening human activity, which we indicated in our Introduction. Consequently we return to the main point of that Introduction, which was to preface, as an educational device, the World Campaign for The Biosphere, that should extend from 1982 for at least several years and also have other worthy 
objectives. These include not only world-wide understanding of the situation, but also realization of how we are all involved and interdependent, and so need to be together in our thoughts and actions.

\section{THE WORLD CAMPAIGN FOR THE BIOSPHERE}

With our enlightened audience of those who subscribe to, or otherwise obtain access to, this Journal, there is no need to dwell futher in general terms on the background and significance of this much-needed enterprise; but it does seem desirable to consider how it may best be furthered. Right from the inception of the idea (Polunin, 1980c), it seemed clear to us that a world body would be needed to organize a suitable launching and global campaign, and thereafter promote and coordinate efforts for maximum effectiveness. For this it appeared that the World Environment and Resources Council (WERC) might be a suitable body (Laconte \& Jones, 1980). But despite their early welcome of the idea (e.g. Laconte et al., 1980), they subsequently found that 'The present membership of WERC does not allow [us] to organize a world-wide campaign for a Biosphere Decade' (Pierre Laconte in litt. 24 December 1981). So, very late for due action, it came back to us to pushhopefully soon 'into the right lap'.

Let me now deal in some detail with the 'round dozen' of means by which, when writing the editorial on pages $6-7$ of our latest issue, that was intended to preface the stressing in this one of the Decade, now renamed Campaign, it seemed (and still seems) clear to us that the latter might best be promoted and fostered, while calling for further ideas. And although most of our own activities are carried on without special financing, I do feel that some will be needed for effective promotion of the World Campaign for The Biosphere, and to such ends would welcome suggestions of methods and possible sources of financing (see also several of the numbered items below). This will be for transmission to the adopting body, or if necessary for activation through our own Foundation for Environmental Conservation, which has also adopted this theme of the Campaign for The Biosphere.

1) Publishing and Broadcasting Information and Support by All Appropriate Means: - This should include editorials, survey articles, and research topics, in such widecirculation but high-level journals as Science, Nature, New Scientist, and Scientific American, and also in such general environmental journals as Environmental Conservation, Ambio, The Ecologist, The Environmentalist, $M a-$ zingira, and a few others of international circulationto mention only some in English. In addition, the daily and other 'popular' press should be involved through such internationally-oriented newspapers as The Times, The New York Times, The International Herald-Tribune, and their counterparts in other languages having a widely international readership. If the big internationals lead the way with persistence and inspiration, the local but often widely-quoted press will surely carry on the message.

2) Other Vehicles of Desirable Publicity, Including Posters and Stickers:-Chronically involved should be such further 'media' as television, documentary and even fictional films and writing, radio broadcasting, the pulpit, and possibly the 'flesh and blood' stage - see also 3 and 8 below. Into all should be inculcated the vital importance of real knowledge of The Biosphere and the urgency of passing on this knowledge to the widest possible audience everywhere-see also the following two items. Means must be found to make proprietors and exponents of the various media, and ultimately their clients and supporting public, really interested and involved. Could not they be cajoled into giving time, space, or whatever, for the good of this all-important cause of furthering the environmental movement and ultimately saving our world?

At pertinent conferences* and widely elsewhere, there should be displays of coloured posters illustrating various leading features of The Biosphere and its supporting Campaign, while vivid 'stickers' for cars etc.- - such as INSONA's 'Save Our Biosphere' (Gaekwad \& Oza, 1981) one duly amended (Fig. 1) - should be widely used, as suggested by Vallentyne (MS.). We can even visualize them as constituting the medium of a world competi-

\footnotetext{
*Such as the UNESCO-ICSU event described on pp. 74-5 of our preceding issue.-Ed.
}

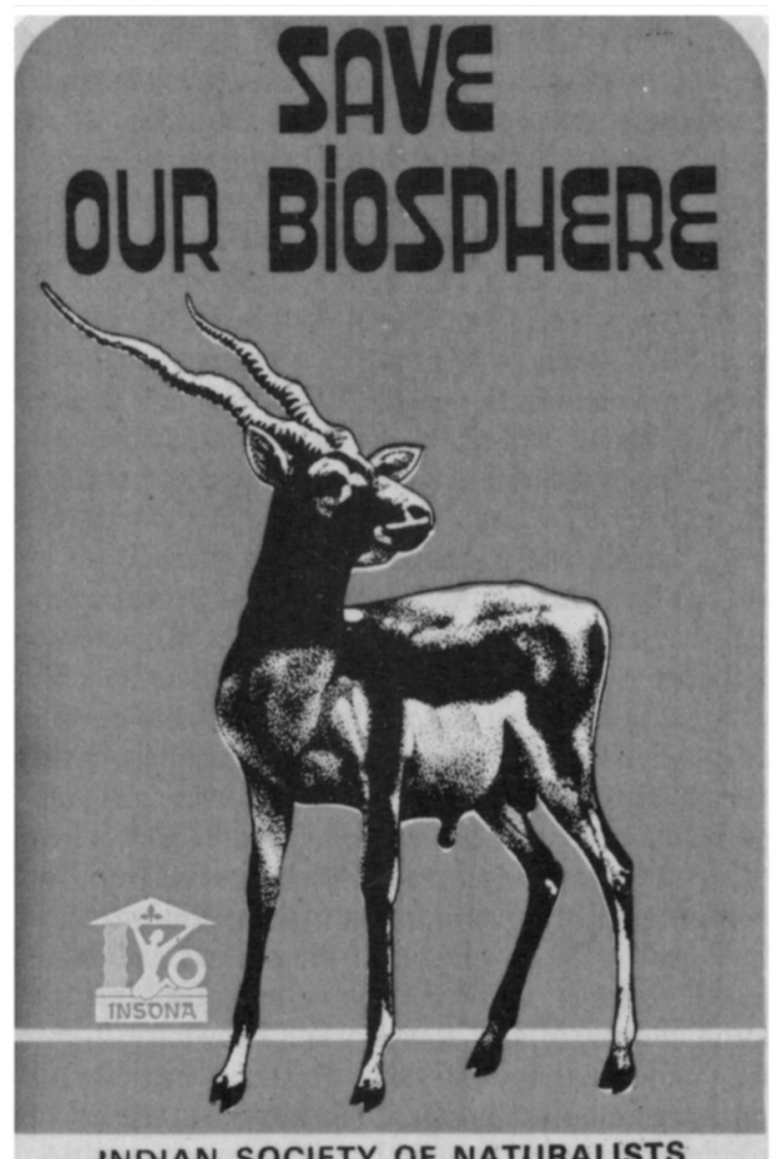

Fig. 1. The revised INSONA sticker with 'OUR' inserted in the heading and the full title of the Society below. Similarly black and white on a bright-green background, it was received from India within a matter of days of our pointing out such needs (see also Gaekwad \& Oza, 1981). 
tion, entries for which children and others might collect with avidity.

3) Instructive Advertising and Audience-attracting Showmanship:-One of the prevailing means of changing peoples' attitudes through improving their knowledge and understanding is by means of advertizing in various media - including those already mentioned and also newspaper notices and announcements. But however this may be done by or for us, it must be dignified and scientifically sound, wholly accurate throughout (unless obviously farcical), and strictly factual without ever being unduly alarmist. Unfortunately, media advertising is nowadays apt to be far too costly for most leaders and others in the environmental movement to pay for personally. However, governments and major industries (which often have far larger budgets!) cannot afford to have happen the kind of things that ecologists and realistic demographers feel bound to warn them about, and herein should lie the basis of advertising bill-footing on behalf of The Biosphere.

4) Books on The Biosphere and Illustrated Study Manuals: - Needed are a popular but scientifically-based volume on The Biosphere, with a mass-produced and inexpensive paperback edition, and illustrated studymanuals (for examples on particular regions or biomes and their component ecosystems). These could help with enlightenment and due guidance, and should not be distributed free but bought at the lowest possible priceespecially in the poorer regions and countries. Another idea which we have in mind to implement at the earliest opportunity for book-writing could come in here.

As for what he himself calls 'audience-attractiving showmanship', I think of our enthusiastic colleague Jack Vallentyne's bicycling with his symbolic Biosphere on his back-widely in North America and Eurasia eastwards to Japan (cf. Polunin, 1980c, Fig. 1; Vallentyne, 1981). This is something which the inquisitive public may wonder about but at least will tend to remember (Fig. 2)!

5) Specialist Research and Due Applications:-Although it is true that the answers to many looming questions are known (at least to enlightened workers), and that what is now widely needed is due application of such knowledge, there can scarcely be too much basic research and applicational testing of pertinent results emanating from it. This is particularly true where ever-changing life and its environments are concerned. Moreover, who can tell, at any particular stage, what research results are pertinent and even important for application? So we must push on with more and more basic and relevant applied research, and with the widest possible dissemination and use of new as well as old knowledge-chronically remembering the great Faraday's proverbial response regarding his electrical sparks: 'What use is a newborn baby?'.

6) Need to Control Human Numbers and Behaviour:-Perhaps the most fundamental thing that Man has so far failed to do is to control his own numbers, despite having the necessary means and knowledge of how to undertake it humanely. So the remedy is left to

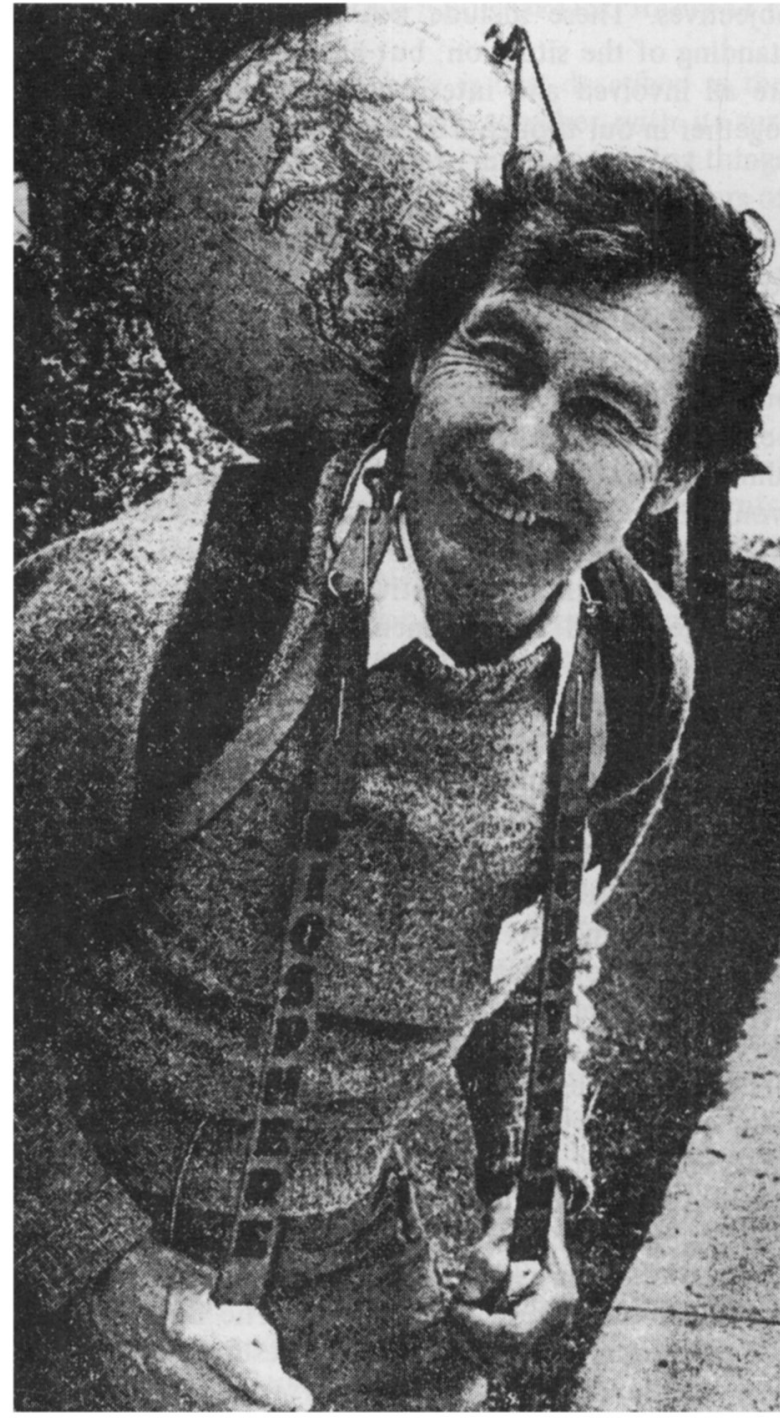

Fig. 2. DrJ. R. Vallentyne, of Burlington, Ontario, Canada, with his 'Biosphere' which he wears on his back as a symbol of global unity on behalf of our intructional campaign for The Biosphere. A former Professor of Zoology at Cornell University and President of the International Association of Limnology, and currently President of the Canadian Society of Environmental Biologists and Chairman of the Rawson Academy of Aquatic Science, Dr Vallentyne reckons that he must have been seen with his globe by some 200 million people in the past two years, mostly in newspapers and on television. The words on the straps which he holds with his hands are reading downwards, 'BIOSPHERE' and 'ECOSYSTEM'. The photograph and an accompanying article appeared on the front page of the Columbus Citizen-Journal on 29 April 1981.

Nature's way of famine and/or pestilence, or to Man's way of increased violence. But why? And how can this ever-worsening situation best be remedied? Yet remedied it must be, if our world is not to deteriorate widely into a situation of dreary monocultures and widespread squalor. Of the need for such a remedy, environmental education and due awareness should at least provide an overdue warning, while widely pointing the way to stewardly care and ultimate amelioration. 
7) National Parks, Biosphere Reserves, and Biological Gardens, etc.: - The National Parks and Protected Areas Movement has gathered considerable momentum in recent years, inter alia in relation to the rights of indigenous peoples and some integration with development (cf. Eidsvik, 1980; Guppy, 1980). It is now extending actively into the marine environment, while further useful educational tools - ranging from the research to the popular levels - to invoke in support of the World Campaign for The Biosphere, include the Man and the Biosphere Programme and Biosphere Reserves (Batisse, 1980, 1982), together with Biological (rather than merely Botanical or Zoological) Gardens. The inspiration of a wilderness area can be supreme, and communion with Nature an aesthetic experience leading to productive enlightenment. As for such further devices as the World Conservation Strategy, the Campaign often seems to us a prerequisite to wide public understanding for their successful implementation.

8) Conferences, Meetings, and Other 'Free' Deliberations:- The launching and prosecution of the World Campaign for The Biosphere should, as already indicated, be accompanied by widespread but dignified publicity. The Campaign is to be fostered and furthered at and by our Third International Conference on Environmental Future, which should include some elucidation of problems of The Biosphere and its equable maintenance. In addition, the first World Environmental Education Conference, postponed from 1982, is expected to include due consideration of the theme of education for the protection of The Biosphere. Moreover, a further series of symposia, culminating in a world conference, is being planned by WERC 'to deal with the wise management of biospheral resources' (Laconte et al., 1980), while the US National Association for Environmental Education is contemplating various actions including making the Campaign the main theme of its 1984 international conference, which is to be held in Canada. We can also visualize an early planning workshop and, for the year 1985 or soon thereafter, a high-level international seminar or wider conference (such as an ICEF) of world leaders to consider all aspects of the Campaign and, in particular, its most desirable future and outcome.

9) Need to Change Human Attitudes: - Whether or not there is need to change to a 'new international economic order', it seems important that peoples' attitudes towards the future should change in consideration of 'generations yet unborn', and only right to preserve options for them by such means as limiting ourselves to efficient use of the remaining stocks of certain 'hard' minerals and fossil fuels. There is also a dire need to change radically our attitudes vis-à-vis 'workers on the land' and 'traditional peoples', for they are the ones who will know most intimately their own small pieces of 'The Biosphere'-whatever they may call it-moreover understanding its needs and how it can best be fostered. Indeed it may well prove to be ultimately on them, rather than on politicians or industry or even Big Agribusiness that, with the erosion or ignorant destruction of more-and-more of our life-support system, con- temporary humanity may find itself dependent for food and much else. Here again, and very widely but not always, we should 'act small' while commonly thinking big.

10) Need to Establish Due Ethics and Laws:-In their aggregate paper 'Ethics of Biospheral Survival', contributed from the vantage point of cultures based on four different continents, Willard et al. (1980) emphasize the need for fresh thinking and ethics on behalf of The Biosphere, while Widman \& Schram (1980) deal with the hopes for 'Common Laws for Earth and Mankind' in a similarly innovative fashion. These papers were prepared for, and presented in outline at, our Second International Conference on Environmental Future, and engendered long and lively discussions which are published in the main in the Conference proceedings (Polunin, 1980d). But much more of this kind of thinking - and concomitant action towards ultimate implementation-is urgently needed. For without due ethical re-thinking 'in the corridors of power', and along the wider roads that lead to them and in edicts that stem from them, there can be little room to hope for a better world, while one of the most obvious needs for the future will surely be suitable laws and their enforcement for Man and Nature.

11) Institutional and Organizational Involvement towards Survival: - It is important that a large number and wide range of leading international organizations and institutions, national and other academies and associations, and university and other departments and research institutes, etc., participate in fostering and promoting the World Campaign for The Biosphere. Such agencies etc. as UNEP, IUCN, INTECOL, ICEFs, WERC, and WWF (our cover-cited collaborators in maintaining Environmental Conservation), are obvious cases in point, while other notable ones should include UNESCO, FAO, WMO, WHO, The World Bank, and perhaps further UN Agencies, the Smithsonian Institution and various national and other museums, and pertinent government departments and research institutes. The Red Cross, OECD, various religious factions, the Sierra Club, Friends of The Earth, Institut de la Vie, World Scouting, etc., should all be actively involved, as should many lesswidely-influential organizations. Already at their latest General Assembly the global International Association of Limnology (SIL) formally endorsed our initiative, while the large and powerful North American National Science Teachers Association and the National Association for Environmental Education have both set up special committees to support what is turning out to be the World Campaign for The Biosphere. Moreover the last-named organization, according to a letter received recently from its President, is contemplating making this the topic of their next international conference (as already noted above*).

Although a micro-secretariat of not more than four well-chosen persons with reasonable wherewithal for communications etc. may prove desirable, it is not con-

*And further discussed with incipient plans during a visit which he subsequently paid us in Toronto, Canada, in June 1982. 
sidered necessary to have any major budget to promote most aspects of the Campaign; indeed the absence of major financing might well be an advantage inter alia in limiting the promotors to enthusiastic scholars and other dedicated workers lacking financial aspirations and concomitant self-promotional ambitions.

12) 'Guardians of The Biosphere' Recognition and Awards:-We are firmly convinced that substantial betterment would accrue to the prospects of our tottering world if only people everywhere would learn about The Biosphere and realize their responsibilities, as its stewards, to preserve and foster it in all possible ways, applying this stewardship to their day-to-day as well as long-term actions. Might not such learning and cognate behaviour then take the place of the fervoured discipline (e.g. stemming from religious beliefs) whose erosion in the modern world is so much to be deplored? To become thus the profoundly conscious (and why not recognized or even official?) Guardians of The Biosphere, should give to all such adherents a feeling of real accomplishment and lasting 'togetherness'. A pervading attitude of 'this is Our Biosphere to cherish and maintain', should then underlie their concerted resolve to preserve peace on Earth and do all in their power, individually and collectively, to assure for Man and Nature a lastingly robust future. True Guardians of The Biosphere should be universally recognized as feeling and practising their full responsibility towards ensuring this.

\section{ACKNOWLEDGEMENTS}

This paper stems in part (and quotes widely) from one given at the Oxford International Symposium, on Environment and the Use of Resources, which was held in Christ Church, Oxford, England, during 22-27 September 1980, and in part from an invited lecture delivered on 26 August 1981 in Sydney, Australia, at the XIII International Botanical Congress, to the organizers (and for the excellent organization) of both of which memorably enjoyable events the Author's thanks are due and warmly given.

Grateful tribute is also paid to those who helped with the drafting or polishing (but not necessarily finalization) of the 'Open Letter' of concern and/or 'Declaration' of the Campaign that start this issue-particularly John R. Vallentyne, Mostafa K. Tolba, Carole A. TrangmarPalmer, Gilbert F. White, Bert R. J. Bolin, Ivan Polunin, and Linus Pauling (in approximate chronological order).

\section{SUMMARY}

After a requested account of how, starting from his student days, he had come gradually to 'care about our Only One Biosphere' and think globally (even if commonly acting only locally), the Author presents his 'thoughts on what might best be done to [foster a World Campaign for The Biosphere] and make it operationally effective'. This Campaign should be world-wide and have the objective of educating everybody everywhere to full realization of the following facts and their often imperatively grave implications: (1) The Biosphere constitutes a single integrated whole of which all parts are often intricately interdependent, (2) we humans form an integral part of
The Biosphere but are becoming far too numerous and heavily dominant for its or our own good, (3) we are absolutely dependent on the health of The Biosphere for our own subsistence and more as it constitutes our sole life-support, (4) The Biosphere in part or even in toto is in several ways fragile, but (5) it is gravely threatened by various human activities and out-sized capabilities such as those of nuclear weaponry which are said to be sufficient to destroy our civilization several times over, and conceivably even the entire Biosphere.

The second, longer part of the article is devoted to consideration of the following chosen 'round dozen' recommended activities through which it is thought the Campaign might best be advanced, at least in its early stages: (1) Publishing and broadcasting pertinent information and support by all appropriate means; (2) Using other vehicles of desirable publicity, including posters and stickers; (3) Instructive advertising and audienceattracting showmanship; (4) Books on The Biosphere and illustrated study manuals; (5) Specialist research and its vigorous application; (6) Need to control human numbers and behaviour; (7) National Parks, Biosphere Reserves, and Biological Gardens, etc.; (8) Pertinent conferences, meetings, and other 'free' deliberations; (9) Need to change human attitudes and priorities; (10) Need to establish due ethics and laws;(11) Institutional and organizational involvement towards survival; and (12) 'Guardians of The Biosphere' recognition and awards.

The above 12 points largely follow those presaged in the Editorial in our preceding issue, since completion of which it has emerged that this Campaign should be socalled (without reference to any time-scale), and that it might best be furthered by two United Nations agencies, an intergovernmental one, and at least one nongovernmental one-all hopefully working in concert.

\section{REFERENCES}

BATISSE, Michel (1980). The relevance of MAB. Environmental Conservation, 7(3), pp. 179-84, map.

BATISSE, Michel (1982). The Biosphere Reserve: A tool for environmental conservation and management. Environmental Conservation, 9(2), pp. 101-11,8 figs.

CLOUD, Preston (1980). An International Year of The Biosphere? Environmental Conservation, 7(2), p. 92.

EIDSVIK, Harold K. (1980). National Parks and protected areas: Some reflections on the past and prescriptions for the future. Environmental Conservation, 7(3), pp. 185-90.

GAEKWAD, Fatesinghrao P. \& OZA, G. M. (1981). Save our Biosphere. Environmental Conservation, 8(2), pp. 117-8, fig.

GREGORY, Philip H. (1973). The Microbiology of the Atmosphere, 2nd edn. (A Plant Science Monograph: General Editor, Nicholas, Polunin.) Leonard Hill, London, England, UK: xxi +377 pp., illustr.

GUPPY, Nicholas (1980). Some crucial issues of our time. Environmental Conservation, 7(1), pp. 3-8.

HIATT, Howard H. (1981). Foreseeable medical consequences of use of nuclear weapons. Environmental Conservation, 8(4), pp. 263-7.

JOHNSON, Stanley P. (1980). The pandominance of Man. Pp. 173-94 and following discussion to p. 207 in Polunin (1980d, q.v.).

LACONTE, Pierre \& JONES, Philip H. (1980). The World Environment and Resources Council (WERC). Environmental Conservation, 7(2), pp. 91-2. 
LACONTE, Pierre, JONES, Philip H. \& HUGHES-EVANS, David (1980). Open Letter: Support for The World Decade of The Biosphere, 1982-92. Environmental Conservation, 7(4), pp. 257-8.

MEIER, Fred C. \& LINDBERGH, Charles A. (1935). Collecting microorganisms from the arctic atmosphere... "with field notes and material' by Charles A. Lindbergh. Scientific Monthly, 40, pp. 5-20.

POLUNIN, Nicholas (1951a). Seeking airborne botanical particles about the North Poles. Svensk Botanisk Tidskrift, $45(2)$, pp. $320-54$, illustr.

POLUNIN, Nicholas $(1951 b)$. Arctic aerobiology: Pollen grains and other spores observed on sticky slides exposed in 1947. Nature (London), 168, pp. 718-21, illustr.

POLUNIN, Nicholas (1955). Arctic aeropalynology: Spores observed on sticky slides exposed in various regions in 1950. Canadian Journal of Botany, 33, pp. 401-15.

POLUNIN, Nicholas (1972). The biosphere today. Pp. 33-52 and following discussion etc. to page 64 in The Environmental Future (Ed. Nicholas Polunin), The Macmillan Press, London \& Basingstoke, England, UK, and Barnes \& Noble, New York, NY: xiv +660 pp., illustr.

POLUNIN, Nicholas [as N.P.] (1980a). Editorial: Environmental education and The Biosphere. Environmental Conservation, 7(2), pp. 89-90.

POLUNIN, Nicholas [as N.P.] (1980b). Editorial: The forthcoming World Decade of The Biosphere, 1982-92. Environmental Conservation, 7(4), p. 257.

POLUNIN, Nicholas $(1980 \mathrm{c})$. Suggested actions for the forthcoming 'World Decade of The Biosphere'. Environmental Conservation, 7(4), pp. 271-7, fig.

POLUNIN, Nicholas (Ed.) (1980d). Growth Without Ecodisasters? Proceedings of the Second International Conference on Environmental Future (2nd ICEF), held in Reykjavik, Iceland, 5-11 June 1977. Macmillan, London \& Basingstoke, England, UK, and Halsted Press Division of John Wiley \& Sons, New York, NY, USA: xxvi + 675 pp., illustr.

POLUNIN, Nicholas [as N.P.] (1982). Human aspirations, environmental care, and the much-needed World Decade of
The Biosphere. Environmental Conservation, 9(1), pp. 6-7.

POLUNIN, Nicholas \& KELLY, C. D. (1952). Arctic aerobiology: Fungi and Bacteria, etc., caught in the air during flights over the geographical North Pole. Nature (London), 170, pp. 314-6.

POLUNIN, Nicholas, PADY, S. M. \& KELLY, C. D. (1947). Arctic aerobiology. Nature (London), 160, pp. 867-7, map.

POLUNIN, Nicholas, PADY, S. M. \& KELLY, C. D. (1948). Aerobiological investigations in the Arctic and Subarctic. Arctic (Journal of the Arctic Institute of North America), 1(1), pp. 60-1.

VALLENTYNE, John R. (1980). Early reactions to the concept of 'The International Year of The Biosphere'. Environmental Conservation, 7(2), pp. 97-9.

VALLENTYNE, John R. (1981). Origin of the proposal for the World Decade of The Biosphere, 1982-1992. The Environmentalist, 1(3), pp. 244-6.

VALLENTYNE, John R. (MS.). I am a 'Save Our Biosphere' Sticker Distributor. Typescript submitted from Burlington, Ontario, Canada: $3 \mathrm{pp}$. [Published in updated form on page 111 of this issues. -Ed.]

VALLENTYNE, John R., STRICKLER, J. R. \& POLUNIN, Nicholas (1980a). Battle for the Biosphere. Environmental Conservation, 7(2), pp. 90-1.

VALLENTYNE, John R., STRICKLER, J. R. \& POLUNIN, Nicholas $(1980 b)$. Proposal: International Year of The Biosphere. Environmental Conservation, 7(1), p. 2.

- WESTING, Arthur H. (1981). Environmental impact of nuclear war. Environmental Conservation, 8(4), pp. 269-73.

WIDMAN, Gary L. \& SCHRAM, Gunnar G. (1980). Common laws for Earth and Mankind: A glorious hope? Pp. 515-68 and following discussion to page 579 in Polunin (1980d, q.v.).

WILLARD, Beatrice, E., ASIBEY, Emmanuel, O. A., HOLDGATE, Martin W., FUKUSHIMA, Yoichi \& GRAY, Elizabeth \& David Dodson (1980). Ethics of biosphere survival: A dialogue. Pp. 505-35 and following discussion to page 551 in Polunin (1980d, q.v.).

WORTHINGTON, E. Barton (1982). World Campaign for The Biosphere. Environmental Conservation, 9(2), pp. 93-100.

\section{A Message of Support for Life}

The following 'Statement of the Environmental NGOs present at the Session of a Special Character of the Governing Council of the United Nations Environment Programme', which was held in the Kenyatta International Conference Centre, Nairobi, Kenya, during $10-18$ May 1982, was prepared primarily in English but read in Spanish to a plenary meeting of the Session, with some 150 NGO representatives standing in support.

\section{Introduction}

1. We, citizens of 55 nations, free and together, believe there was never a moment in history when a change in course was more vital. We cannot close our eyes to the continuing degradation of the environment. The current development process, in the North and the South, the East and the West, is everywhere beset by similar dangers, and is itself the fundamental cause of environmental degradation. Despite all the difficulties confronting the people of the world, a new kind of development, human and environmental, must emerge. It is the unique responsibility of this generation to accept that challenge and to work together to secure the future.

2. In the ten years since the Stockholm Conference, the prospect for the human environment has darkened rapidly. The development processes that degrade the human environment are also those which degrade the human condition. They have continued to accelerate. Governments every where have failed to carry forward the spirit of Stockholm. Unratified conventions, unenforced laws, underfunded agencies, inadequate national institutions, and declining support for international efforts, have traced a record of neglect and irresponsibility.
Such efforts as have been made have dealt with symptoms rather than causes; they have failed to recognize the urgency of global problems and the need to devise fundamentally new approaches to development, if environmental problems are to be solved.

\section{Natural Environment}

3. The state of the environment is bleak:

- Croplands and rangelands are everywhere under increasing stress, threatening agricultural productivity;

- Forests, particularly tropical rain-forests, are rapidly declining in area;

- While the deep oceans are not yet known to be significanly damaged, coastal zones, and their important fisheries, are being degraded in many parts of the world; exploration and exploitation of deep-ocean minerals and oil in the coming decade threaten the marine environment;

- Air quality is improving in some localities, but worsening in more; acid precipitation and photochemical pollution are acute problems in many regions, and the long-term threat to the atmosphere from carbon, sulphur, and nitrogen, oxides is growing;

- The quality of inland waters is improving in some places and deteriorating in more, and the availability of fresh water is not keeping pace with minimum requirements; - Human settlements are continuing to expand over increasing areas of valuable agricultural land; the quality of the landscape and of urban areas continues to decline; - Biological diversity continues to decline at a rate unknown in history, as species-loss accelerates through destruction of natural habitat. 